\title{
FEATURES OF FOREIGN TRADE BETWEEN RUSSIA AND CHINA AND PROSPECTS FOR ITS DEVELOPMENT
}

\author{
Nikolay Yakushev ${ }^{1}$, Ekaterina Khusainova ${ }^{2}$, Tatiana Maksimova ${ }^{3}$, Lazar Badalov ${ }^{4}$ \\ ${ }^{1}$ Vologda research center of the Russian Academy of Sciences \\ ${ }^{2}$ Kazan State Power Engineering University, str. Krasnoselskaya, 51, 420066, Kazan, Russia \\ ${ }^{3}$ Plekhanov Russian University of Economics, Department of the Economic theory, 117997, Moscow, Russia \\ ${ }^{4}$ Financial University under the Government of the Russian Federation, Departament of world finance, 125993, Moscow, Russia
}

\begin{abstract}
Trade and economic relations are the main basis for partnership and strategic cooperation between Russia and China. This paper examines the place of Russia and China in global trade. The main strategic priority in the development of trade and economic relations between Russia and China is indicated. The analysis of Russian-Chinese foreign trade turnover for the period from 2001 to 2018 is presented. The main product groups in Russian-Chinese foreign trade are analyzed and promising areas for further development are identified.
\end{abstract}

\section{Introduction}

Export development is determined by the country's foreign economic policy, which is focused on the implementation of the state's strategic goals and objectives in relations with other States and their integrated international organizations. One such example is the foreign trade cooperation between Russia and China $[1 ; 2]$.

At the same time, in the current circumstances of the emerging threat to the global trade flow and the global economy as a whole, it is fundamentally important for Russia to correctly identify priorities in foreign trade with China in the most promising export directions as a source of economic growth $[3 ; 4]$.

In this regard, the purpose of the work is to determine the trends and prospects for development in foreign trade between Russia and China. To achieve this goal, it is necessary to implement the following tasks: clarify the place of Russia and China in global trade, analyze the state of Russian-Chinese foreign trade turnover, and identify areas of development in foreign trade between the countries.

In global trade, the development of Russia and China is characterized by the following features [5]:

for Russia: the share in world exports in 2018 is $2.3 \%$, and imports are $1.2 \%$; in the period from 2001 to 2018 , there is an increase in export volumes by 4 times, and foreign trade turnover by 4.8 times.

For China: it has been a leader in world exports since 2007 , its share in 2018 was $12.9 \%$; it is one of the top three importers in the world with a share of $10.9 \%$ (as of 2018); the volume of foreign trade turnover and exports for 2001-2018 increased 9 times.

One of the main strategic priorities in the development of global trade for Russia and China is the integration of the "one belt, one road" initiative and the Eurasian economic Union. At the end of 2018, the trade turnover between Russia and China for the first time amounted to 108.3 billion us dollars. Trends in the

Table 1. Indicators that reflect the level of innovation development in the Russian manufacturing industry.

\begin{tabular}{|c|c|c|c|c|c|c|c|}
\hline Indicator & 2001 & 2008 & 2009 & 2016 & 2017 & 2018 & $\begin{array}{c}\text { Changing } \\
2018 \text { to } 2001, \% \\
\end{array}$ \\
\hline \multicolumn{8}{|c|}{ Billion US dollars } \\
\hline Export from Russia to China & 5.6 & 20.3 & 16.1 & 28.0 & 37.5 & 56.0 & 10 times \\
\hline Import from China to Russia & 1.6 & 34.8 & 22.9 & 38.1 & 48.4 & 52.3 & 32 times \\
\hline \multicolumn{8}{|l|}{1} \\
\hline Share of Russia in China's exports & 1.0 & 2.3 & 1.5 & 1.8 & 1.9 & 1.9 & +0.9 \\
\hline Russia's share in China's imports & 3.4 & 2.3 & 2.3 & 2.0 & 2.4 & 3.0 & -0.4 \\
\hline China's share in Russia's exports & 5.6 & 4.5 & 5.5 & 9.8 & 10.4 & 12.5 & +6.9 \\
\hline China's share in Russia's imports & 3.9 & 13.0 & 13.4 & 20.9 & 21.2 & 21.9 & +18.0 \\
\hline
\end{tabular}


Table 2. the Main commodity groups of foreign trade turnover of Russia and China (export from Russia)*.

\begin{tabular}{|c|c|c|c|c|c|c|c|}
\hline \multirow[b]{2}{*}{ Name of the product group } & \multirow{2}{*}{$\begin{array}{c}2004 \\
\text { (millions } \\
\text { US } \\
\text { dollars) }\end{array}$} & \multicolumn{2}{|c|}{$\begin{array}{c}\text { Share (\%) in the total } \\
\text { amount: }\end{array}$} & \multirow{2}{*}{$\begin{array}{c}2018 \text { г. } \\
\text { (millions } \\
\text { US } \\
\text { dollars) }\end{array}$} & \multicolumn{2}{|c|}{$\begin{array}{l}\text { Share ( \%) in the total } \\
\text { amount: }\end{array}$} & \multirow{2}{*}{$\begin{array}{c}\text { Changes in } \\
\text { the share } \\
\text { of exports } \\
\text { to China } \\
2018 \text { to } \\
2004\end{array}$} \\
\hline & & $\begin{array}{l}\text { Export to } \\
\text { RPC }\end{array}$ & PG export & & $\begin{array}{l}\text { Export to } \\
\text { RPC }\end{array}$ & PG export & \\
\hline $\begin{array}{l}\text { Food products and raw materials for their } \\
\text { production }\end{array}$ & 112.9 & 1.3 & 4.6 & 2523.6 & 4.5 & 10.1 & 3.2 \\
\hline $\begin{array}{l}\text { Mineral products, including fuel and } \\
\text { energy products }\end{array}$ & 3087.4 & 36.1 & 3.1 & 42718.7 & 76.2 & 14.6 & 40.1 \\
\hline Chemical industry products & 1268.3 & 14.8 & 11.7 & 1585 & 2.8 & 5.8 & -12 \\
\hline $\begin{array}{l}\text { Leather raw materials, furs, products from } \\
\text { them }\end{array}$ & 9.0 & 0.1 & 3.6 & 5.9 & 0.0 & 2.3 & -0.1 \\
\hline Wood, paper and products made of them & 1407.5 & 16.5 & 20.9 & 4834.7 & 8.6 & 34.8 & -7.9 \\
\hline Textiles, textile products, footwear & 8.3 & 0.1 & 1.2 & 11.7 & 0.0 & 1.0 & -0.1 \\
\hline Metals and products made of it & 1621.9 & 19.0 & 5.7 & 1335.6 & 2.4 & 3.1 & -16.6 \\
\hline Machinery, equipment, vehicles & 1030.2 & 12.1 & 8.4 & 1829.4 & 3.3 & 6.3 & -8.8 \\
\hline Others & 4.2 & 0.0 & 0.2 & 1195.9 & 2.2 & 6.9 & 2.2 \\
\hline \begin{tabular}{|l|} 
Total \\
\end{tabular} & 8549.7 & 100 & - & 56040.5 & 100 & - & - \\
\hline
\end{tabular}

Table 3. Main commodity groups of foreign trade turnover in Russia and China (import from China)*.

\begin{tabular}{|c|c|c|c|c|c|c|c|}
\hline \multirow{2}{*}{ Name of the product group } & \multirow{2}{*}{$\begin{array}{c}2004 \\
\text { (millions } \\
\text { US } \\
\text { dollars) }\end{array}$} & \multicolumn{2}{|c|}{$\begin{array}{c}\text { Share (\%) in the total } \\
\text { amount: }\end{array}$} & \multirow{2}{*}{$\begin{array}{c}2018 \text { г. } \\
\text { (millions } \\
\text { US } \\
\text { dollars) }\end{array}$} & \multicolumn{2}{|c|}{$\begin{array}{l}\text { Share (\%) in the total } \\
\text { amount: }\end{array}$} & \multirow{2}{*}{\begin{tabular}{|c|}
$\begin{array}{c}\text { Changes in } \\
\text { the share }\end{array}$ \\
of exports \\
to China \\
2018 to \\
2004 \\
\end{tabular}} \\
\hline & & $\begin{array}{l}\text { Export to } \\
\text { RPC }\end{array}$ & PG export & & $\begin{array}{l}\text { Export to } \\
\text { RPC }\end{array}$ & PG export & \\
\hline $\begin{array}{l}\text { Food products and raw materials for their } \\
\text { production }\end{array}$ & 440.5 & 9.4 & 3.4 & 1899.3 & 3.6 & 6.4 & -5.8 \\
\hline $\begin{array}{l}\text { Mineral products, including fuel and } \\
\text { energy products }\end{array}$ & 87.2 & 1.9 & 3.2 & 206.2 & 0.4 & 4.1 & -1.5 \\
\hline Chemical industry products & 365.3 & 7.8 & 3.2 & 5172.3 & 9.9 & 11.9 & 2.1 \\
\hline $\begin{array}{l}\text { Leather raw materials, furs, products from } \\
\text { them }\end{array}$ & 80.4 & 1.7 & 39.8 & 602.5 & 1.2 & 47.4 & -0.5 \\
\hline Wood, paper and products made of them & 88.5 & 1.9 & 3.4 & 483.8 & 0.9 & 12.3 & -1 \\
\hline Textiles, textile products, footwear & 745.0 & 15.9 & 29.1 & 5834.4 & 11.2 & 39.3 & -4.7 \\
\hline Metals and products made of it & 276.3 & 5.9 & 5.4 & 4045.4 & 7.7 & 23.7 & 1.8 \\
\hline Machinery, equipment, vehicles & 2016.2 & 42.9 & 7.0 & 29824.4 & 57.1 & 26.5 & 14.2 \\
\hline Others & 599.4 & 12.8 & 22.5 & 4149.8 & 7.9 & 40.2 & -4.9 \\
\hline Total & 4698.8 & 100 & - & 52218 & 100 & - & - \\
\hline
\end{tabular}

Russian-Chinese foreign trade turnover in the period from 2001 to 2018 show positive changes with an increase in its volume by 15 times (table 1 ).

An analysis of the foreign trade turnover between Russia and China from 2001 to 2018 shows that there is an increase in the volume of exports and imports with the largest increase in the share of Chinese supplies. According to the foreign trade statistics of the Federal customs service of Russia, the following groups of Russian-Chinese trade turnover can be distinguished (table 2).

Analysis of the commodity structure of Russian exports to China shows that in the period from 2004 to 2018 , the largest share in it was occupied by fuel and raw materials. At the same time, non-primary products and in particular ready-made food products, as a 
potential source of economic growth for the development of the territory, accounted for the smallest share of $4.5 \%$, but increased by 1.6 percentage points compared to 2004 .

In 2018, the largest share of all-Russian imports from China is occupied by machine-building products- $57.1 \%$, textiles and footwear $-11.2 \%$, and chemical industry products $-9.9 \%$ (table 3 ).

In 2018, compared to 2004, the largest increase in Chinese imports to Russia is observed in the supply of machine-building products, as well as high-processing goods of the manufacturing industry, including household goods. At the same time, there is a decrease in Chinese imports in six positions, including various industrial goods and products that have aesthetic functions (clothing and shoes).

In the analysis of global trade from 2016 to 2018, as well as mirror statistics of absolute growth of supply in the international market was highlighted promising areas of development in foreign trade of Russia and China [6; 7]:

1. For exporting to China:

- products of agriculture and food (sunflower oil; chocolate and confectionery; dairy products shelf stable);

- timber and eco-friendly products;

- mechanical engineering products (optical products and devices, equipment used in the field of medicine);

- building materials;

- complex chemical products and pharmaceutical products.

2. for China's import to Russia:

- machinery and technical goods (digital equipment, computer equipment, electronic devices, etc.);

- chemical industry products (including plastic products for reusable use);

- various products and consumer goods sector.

Thus, according to the results of the study, it can be noted that first, since 2009, the growth of global trade has slowed, and there has been a decline in world exports. Secondly, from 2001 to 2018, the foreign trade turnover of Russia and China increased 15 times, exceeded the planned actual values and amounted to 108.3 billion us dollars. Third, the growth of China's share in Russian exports (2001-2018) increased by $6.9 \%$. Fourth, imports from Russia to China increased by 32 times (2001-2018). Fifth, the structure of exports from Russia to China mainly consists of simple goods and raw materials. Sixth, the structure of imports from China to Russia is represented by all product groups, where machine-building products predominate.

As suggestions for stimulating the development of Russian-Chinese foreign trade cooperation, it is important for the authorities of both countries to take into account the following areas if they are properly interested. First, strengthening the joint capabilities of Russia and China in implementing the "one belt, one road" integration initiative, which is aimed at developing specific projects in the supply logistics and high-tech sectors. Second, the use of the "one belt, one road" integrative initiative and more active participation of Russian exporters (primarily small and medium-sized businesses) to expand opportunities in the Chinese market.

\section{References}

1. E.V. Astakhova, CH Van, Modern trends in trade and economic relations between Russia and China, Fundamental research, 1, 140-145 (2017).

2. A.I. Pisetskaya, L.A. Belova, Foreign trade of Russia and China, trends and prospects // Economics and entrepreneurship, 8(2), 1199-1202 (2017).

3. K. Constantinescu, A. Mattu, M. Ruta, World trade slowdown: cyclical or structural?, The World Bank Economic Review, 34(1), 121-142 (2020).

4. U. M. China, Inc. the task of regulating world trade, Harv. International LJ, 57261 (2016).

5. trade statistics for international business development. URL: https://www.trademap.org/

6. N.O. Yakushev, Problems of development of nonprimary export of Russian regions, 70-78 (Vologda: Wants wounds, 2018)

7. Free access to detailed global trade data. URL: https://comtrade.un.org/. 